\title{
Hipertoniczne roztwory soli w nebulizacji
}

\section{Hypertonic saline solution in the nebulization}

\author{
Andrzej Emeryk', Justyna Emeryk-Maksymiuk ${ }^{2}$, Kamil Janeczek' ${ }^{1}$, Arkadiusz Jędrzejewski ${ }^{3}$ \\ ${ }^{1}$ Klinika Chorób Płuc i Reumatologii Dziecięcej, Uniwersytet Medyczny w Lublinie \\ Kierownik Kliniki: prof. dr hab. n. med. Andrzej Emeryk \\ ${ }^{2}$ Katedra i Zakład Pielęgniarstwa Internistycznego, Uniwersytet Medyczny w Lublinie \\ Kierownik: dr hab. n. med. Agnieszka Zwolak \\ ${ }^{3}$ Katedra i Zakład Pielęgniarstwa Pediatrycznego, Uniwersytet Medyczny w Lublinie \\ Kierownik: dr hab. n. med. Danuta Zarzycka
}

\section{Streszczenie:}

Celem pracy było przedstawienie aktualnego miejsca stężonych roztworów soli morskiej (hipertonicznych roztworów soli) stosowanych w nebulizacji w terapii chorób dróg oddechowych u ludzi. Skupiono się na schorzeniach dolnych dróg oddechowych. Przedstawiono dowody skuteczności hipertonicznych roztworów soli stosowanych w nebulizacji w schorzeniach dolnych dróg oddechowych u dzieci i dorosłych. Szzzególną uwage zwrócono na zapalenie oskrzelików, mukowiscydozę, rozstrzenia oskrzeli i przewlekłą obturacyjną chorobę płuc.

\section{Abstract:}

The aim of the study was to present the current place concentrated sea salt solutions (hypertonic salt solutions) used in nebulization in the treatment of respiratory diseases in humans. The focus was on ailments of the lower respiratory tract. Evidence of the efficacy of nebulized hypertonic saline solutions in upper and lower respiratory diseases in children and adults were presented. Particular attention was paid on bronchiolitis, cystic fibrosis, bronchiectasis and chronic obstructive pulmonary disease.

Słowa kluczowe: hipertoniczny roztwór soli, nebulizacja, nieżyty błony śluzowej nosa i zatok przynosowych, zapalenie oskrzelików, mukowiscydoza, rozstrzenia oskrzeli, przewlekła obturacyjna choroba płuc, astma

Key words: hypertonic saline solution, nebulization, rhinosinusitis, bronchiolitis, cystic fibrosis, bronchiectasis, chronic obstructive pulmonary disease, asthma

\section{Wstęp}

Roztwory chlorku sodu $(\mathrm{NaCl})$ lub roztwory różnych soli występujących w wodzie morskiej $(\mathrm{NaCl}$, chlorek magnezu, siarczan magnezu, siarczan wapnia, siarczan potasu, węglan wapnia, bromek magnezu i inne) są używane $w$ medycynie od bardzo wielu lat $[1,2]$. Z praktycznego punktu widzenia dzielimy je na roztwory:
- izotoniczne (IRS, izotoniczny wodny roztwór soli) - roztwór chlorku sodu $0,9 \%$, potocznie nazywany solą fizjologiczną

- hipertoniczne (HRS, hipertoniczny roztwór soli).

Te ostatnie stosuje się w medycynie w różnych stężeniach: 1-10\%, najczęściej 2,0-4,5\% [3]. Dostępne są jako roztwory donosowe (różne techniki apli- 
kacji) oraz roztwory do nebulizacji (różne nebulizatory) [4].

HRS mają szerokie zastosowanie w ostrych i przewlekłych chorobach zapalno-infekcyjnych górnych i niektórych dolnych dróg oddechowych $[3,5]$. Roztwory HRS podawane w dowolnej formulacji donosowo rozrzedzają zalegającą wydzielinę, ułatwiając oczyszczanie jam nosa, ale też zmniejszają obrzęk i nawilżają błonę śluzową nosa [6]. Szczegółowy opis działania i wskazań do stosowania HRS w przeziębieniach, alergicznym nieżycie nosa oraz nieżycie błony śluzowej nosa i zatok przynosowych przedstawiono niedawno na łamach czasopisma „Alergoprofil” [4].

HRS podawane dooskrzelowo (w nebulizacji) działają jako leki mukoaktywne, należące do grupy leków wykrztuśnych [7]. Mechanizm ich działania opiera się na pobudzeniu sekrecji gruczołowej, zwiększeniu zawartości wody w wydzielinie oskrzelowej oraz zmniejszeniu lepkości wydzieliny zalegającej w drogach oddechowych [8]. Dzieje się tak, gdyż po podaniu dooskrzelowym HRS tworzą wewnątrzoskrzelowy gradient osmotyczny prowadzący do zwiększonego biernego wydzielania wody do dróg oddechowych przez wierzchołkowe kanały akwaporynowe [9]. W badaniach przeprowadzonych u zwierząt wykazano, że stymulują też neurony dróg oddechowych do wyzwalania nabłonkowego wydzielania płynu [10]. Wreszcie - HRS wyzwalają kaszel, zapewniając dalsze mechaniczne usuwanie wydzieliny $z$ oskrzeli [11]. Nebulizacja z HRS może zmniejszać rozprzestrzenianie się patogenów w drogach oddechowych [12]. Nowsze prace wskazują, iż HRS zwiększają działanie bakteriobójcze, wirusobójcze i przeciwzapalne innych leków [13, 14]. Trwają też badania kliniczne nad zastosowaniem HRS w spreju na maseczkach twarzowych u chorych na COVID-19 [15].

\section{Nebulizacja z hipertonicznych roztworów soli}

HRS w formie roztworów do nebulizacji ze względu na swoje właściwości fizykochemiczne nadają się do nebulizatorów pneumatycznych, ultradźwiękowych klasycznych oraz ultradźwiękowych siateczkowych [16, 17]. Dobór odpowiedniego nebulizatora jest kluczowym elementem właściwej depozycji płucnej leku i pożądanego efektu klinicznego. Na rycinie 1 ukazano aktualnie dostępne w praktyce typy nebulizatorów $[17,18]$.

Należy przy tym pamiętać, iż każdy rodzaj nebulizatora ma zalety i wady oraz określone miejsce w aerozoloterapii. Nebulizatory z poszczególnych grup nie są zamienne w prosty sposób [17]. W przypadku nebulizacji z HRS w schorzeniach górnych dróg oddechowych mogą być użyte wszystkie typy nebulizatorów: ultradźwiękowe klasyczne, pneumatyczne (wszystkie rodzaje) oraz ultradźwiękowe siateczkowe [19]. Jednakże w leczeniu schorzeń dolnych dróg oddechowych są zalecane przede wszystkim nebulizatory pneumatyczne lub ultradźwiękowe siateczkowe [20]. Trzeba też pamiętać o kilku podstawowych zasadach prowadzenia skutecznej nebulizacji [17, 20-23]:

- Nebulizacja powinna się odbywać za pomocą sprzętu, z którego zastosowaniem został przebadany dany lek lub produkt medyczny in vitro lub in vivo.

- Należy wybierać nebulizator z możliwością regulacji wielkości cząsteczek produkowanego aerozolu,

Rycina 1. Podział urządzeń do nebulizacji (na podstawie [17, 18]).

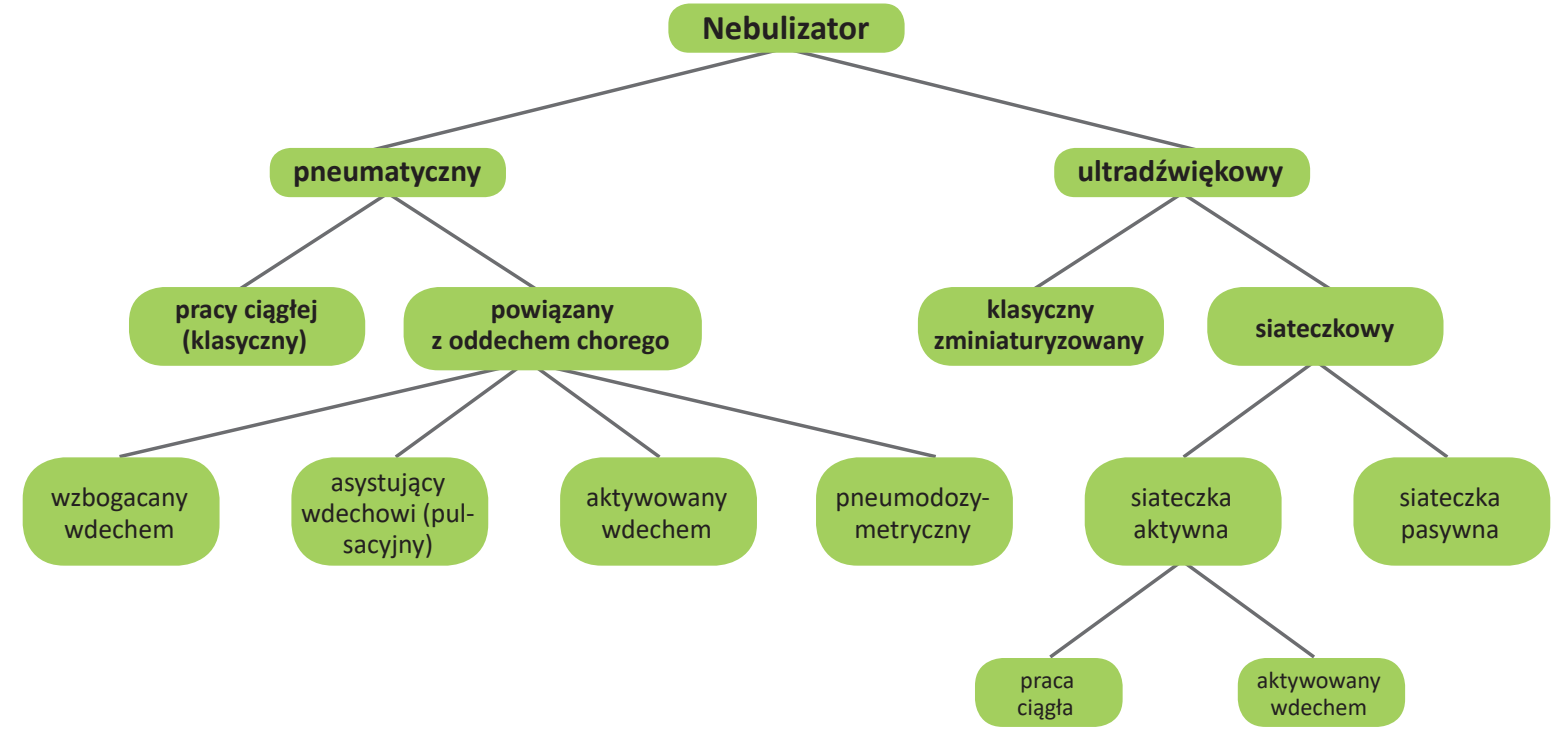


co umożliwi skuteczniejszą depozycję w pożądanych obszarach dróg oddechowych (krtań, tchawica, oskrzela, oskrzeliki).

- Preferowana jest nebulizacja przez ustnik, a maseczka powinna być użyta jedynie u chorych niewspółpracujących i u dzieci < 4.-5. r.ż.

- Zastosowanie inhalatora siateczkowego znacznie skraca czas nebulizacji i prowadzi do istotnie mniejszej straty leku, gdyż urządzenia te mają bardzo małą objętość zalegającą komory nebulizacyjnej (zazwyczaj < 0,5 ml).

- W dobie pandemii COVID-19 należy bezwzględnie stosować filtry wylotowe (dodatkowo montowane), zarówno w nebulizatorach pneumatycznych, jak i siateczkowych używanych w szpitalu.

- Istotna jest technika inhalacji, gdyż wpływa ona na efektywność kliniczną leku i ewentualne działania niepożądane. Na przykład w celu zwiększenia depozycji w obszarze krtaniowo-tchawiczym pacjent powinien wykonywać krótkie, mocne wdechy (co jest możliwe u dzieci po 5. r.ż. i dorosłych).

- Nebulizacja prowadzona w szpitalu powinna być nadzorowana przez wyszkolony personel medyczny, a w warunkach domowych przez przeszkolonego chorego lub jego opiekuna (tzw. terapia nadzorowana)

\section{Hipertoniczne roztwory soli w schorzeniach dolnych dróg oddechowych}

\section{Mukowiscydoza}

Korzystne efekty HRS w tej grupie pacjentów potwierdza jednoznacznie ostatni przegląd systematyczny z metaanalizą, choć autorzy wskazują istnienie dowodów głównie o niskiej jakości [5]. Wykazano bowiem, że:

- HRS w nebulizacji (3-7\%, $10 \mathrm{ml} 2$ razy dziennie) stosowany przez 4 tygodnie u dzieci po 12 . r.ż. i dorosłych powoduje przyrost wartości $\mathrm{FEV}_{1}$ (nasilona objętość wydechowa pierwszosekundowa) o 3,44\% w stosunku do wartości wyjściowej (dowód bardzo niskiej jakości pochodzący z trzech badań, $\mathrm{n}=225$ )

- po 48 tygodniach leczenia efekt ten był nieco gorszy - wzrost FEV jedynie o 2,31\% (dowód niskiej jakości pochodzący z jednego badania, $n=134$ )

- w jednym badaniu (162 osoby dorosłe) stwierdzono istotną redukcję zaostrzeń choroby wymagających antybiotykoterapii w grupie HRS (dowody niskiej jakości)

- w jednym badaniu u dzieci (243 dzieci, średni wiek: 2 lata) nie wykazano efektu terapeutycznego lub był on znacznie mniejszy niż nebulizacja rhDNazy (dowody niskiej jakości)

- HRS wydaje się skutecznym uzupełnieniem fizjoterapii podczas zaostrzeń płucnych tej choroby u dorosłych (dowody bardzo niskiej jakości).

\section{Rozstrzenia oskrzeli niezwiązane z mukowiscydozą}

W przypadku tych schorzeń wykazano, że nebulizacja zarówno HRS, jak i IRS przynosi dość podobne efekty, biorąc pod uwagę wpływ na zaostrzenia choroby, jakość życia pacjentów, kolonizację plwociny i parametry spirometryczne w okresie co najmniej 12-miesięcznej terapii, chociaż efekty 3-miesięcznego leczenia są lepsze po HRS [24, 25]. Nebulizację z HRS uznaje się za standardowe postępowanie w tej grupie chorych [26]. Na bezpieczeństwo terapii HRS u pacjentów z rozstrzeniem oskrzeli zwraca uwagę opracowanie Brytyjskiego Towarzystwa Chorób Klatki Piersiowej (BTS, British Thoracic Society) z 2010 r. [27]. Autorzy tego przewodnika wskazują, iż:

- w przypadku nebulizacji z HRS po raz pierwszy u danego pacjenta należy zmierzyć wartość FEV lub PEF przed leczeniem i 5 min po nim, aby ocenić ryzyko wystąpienia skurczu oskrzeli

- u osób z nadreaktywnością oskrzeli poddawanych nebulizacji z HRS powinno się zawsze wstępnie zastosować lek rozszerzający oskrzela (salbutamol).

\section{Zapalenie oskrzelików u dzieci}

HRS zmieniają właściwości zalegającej w oskrzelikach wydzieliny, co z kolei poprawia oczyszczanie śluzowo-rzęskowe, a dzięki temu również drożność dolnych dróg oddechowych u dzieci chorych na zapalenie oskrzelików [28, 29]. W metaanalizie badań klinicznych z 2018 r. Zhang i wsp. zaznaczają, że redukcja ryzyka hospitalizacji dotyczy tylko dzieci, u których HRS w nebulizacji podawano łącznie z wziewnymi lekami bronchodylatacyjnymi [30]. Jednakże publikacja Harrisona i wsp. (w której wykorzystano metodę analizy sekwencyjnej [trial sequential analysis]) wykazała, iż metaanalizy badań w tym obszarze mogą dostarczać wyników fałszywie dodatnich [31]. Dostępny najnowszy przegląd systematyczny z metaanalizą z $2020 \mathrm{r}$. sugeruje, że nebulizacja HRS może być skutecznym postępowaniem w wirusowym zapaleniu oskrzelików vs roztwory IRS [32]. Niemniej jednak autorzy tej publikacji konkludują, że należy przeprowadzić dalsze badania nad skutecznością zarówno krótkoterminową, jak i długoterminową HRS w nebulizacji. Najnowsza metaanaliza sieciowa, opublikowana w maju 2021 r., wskazuje, że kombinacja HRS (zawsze $z$ salbutamolem) $i$ adrenaliny $w$ nebulizacji jest najefektyw- 
niejszym postępowaniem na SOR (zmniejsza ryzyko hospitalizacji) oraz na oddziale szpitalnym (skraca czas hospitalizacji) vs inne sposoby terapii [33]. Ponadto wykazano, że terapia HRS w nebulizacji jest kosztowo efektywna w grupie niemowląt hospitalizowanych z powodu zapalenia oskrzelików [34]. To wskazanie dla HRS ciągle budzi najwięcej kontrowersji.

\section{Przewlekła obturacyjna choroba płuc}

W przypadku przewlekłej obturacyjnej choroby płuc (POChP) brakuje zalecenia do stosowania HRS w nebulizacji w aktualnym dokumencie GOLD 2021 [35]. Jednakże napływające publikacje wskazują na możliwy korzystny efekt nebulizacji z HRS w niektórych fenotypach POChP, przy dobrej tolerancji leczenia w populacji ogólnej chorych [36].

\section{Astma}

Stosowanie HRS w terapii astmy wzbudza wiele kontrowersji i obecnie nie jest zalecane przez ekspertów w najnowszym Raporcie GINA 2021 [37]. Są jednak badania, których wyniki sugerują, iż taka interwencja może być skuteczna w przypadku zaostrzenia astmy u chorych leczonych $\beta_{2}$-mimetykiem. Podanie HRS w nebulizacji poprawia oczyszczanie śluzowo-rzęskowe i zmniejsza zaleganie śluzu w oskrzelach w przebiegu zakażenia wirusowego lub kontaktu z uczulającym alergenem [38]. Potrzebne są jednak dalsze badania eksperymentalne i kliniczne.

\section{Podsumowanie}

Dooskrzelowa aplikacja HRS w nebulizacji jest uznanym postępowaniem terapeutycznym w niektórych ostrych i przewlekłych schorzeniach dolnych dróg oddechowych przebiegających $\mathrm{z}$ dużym zaleganiem wydzieliny w tchawicy, oskrzelach czy oskrzelikach. Jakość dowodów skuteczności klinicznej HRS w ww. schorzeniach jest jednak na ogół niska, co wynika z bardzo dużych różnic metodologicznych między poszczególnymi badaniami. Dotyczą one np. różnorodnych stężeń HRS, zastosowanych objętości (dawek), sposobów dawkowania, rodzajów nebulizacji i czasu trwania leczenia. Preparaty HRS są na ogół dobrze tolerowane przez pacjentów, zwłaszcza w niższych stężeniach 1,5-2,2\%. Podstawowe wskazania do zastosowania HRS w nebulizacji to: zapalenie oskrzelików, mukowiscydoza i rozstrzenia oskrzeli. Ten rodzaj terapii może być pomocny także w innych stanach chorobowych przebiegających $\mathrm{z}$ zaleganiem wydzieliny w dolnych drogach oddechowych (niektóre postacie zapaleń oskrzeli, POChP). Należy zachować szczegól- ną ostrożność przy nebulizacji z HRS u dzieci i dorosłych z cechami nadreaktywności oskrzeli poprzez poprzedzenie jej inhalacją salbutamolu.

\section{Piśmiennictwo}

1. Wingrave $W$. The nature of discharges and douches. Lancet. 1902: 1373-5.

2. https://pl.wikipedia.org/wiki/Woda_morska (access: 23.07.2021)

3. Kassel JC, King D, Spurling GK et al. Saline nasal irrigation for acute upper respiratory tract infections. Cochrane Database Syst Rev. 2010; (3): CD0068213.

4. Emeryk A, Emeryk-Maksymiuk J, Janeczek $K$ et al. Hipertoniczne roztwory soli $w$ terapii chorób dróg oddechowych. Alergoprofil. 2020; 16(3): 10-7.

5. Wark P, McDonald VM. Nebulised hypertonic saline for cystic fibrosis. Cochrane Database Syst Rev. 2018; 9(9): CD001506.

6. Rabago D, Zgierska A. Saline nasal irrigation for upper respiratory conditions. Am Fam Physician. 2009; 80(10): 1117-9.

7. Balsamo R, Lanata L, Egan CG. Mucoactive drugs. Eur Respir Rev. 2010; 19: 127-33.

8. Linssen RSN, Ma J, Bem RA et al. Rational use of mucoactive medications to treat pediatric airway disease. Paed Respir Rev. 2020; 36: 8-14.

9. Goralski $J L, W u D$, Thelin WR et al. The in vitro effect of nebulised hypertonic saline on human bronchial epithelium. Eur Respir J. 2018; 51: 1702652.

10. Luan X, Tam JS, Belev G et al. Nebulized hypertonic saline triggers nervous system-mediated active liquid secretion in cystic fibrosis swine trachea. Sci Rep. 2019; 9: 540.

11. Elkins MR, Bye PTP. Mechanisms and applications of hypertonic saline. J R Soc Med. 2011; 104(suppl 1): S2-S5.

12. Safdar A, Shelburne SA, Evans SE et al. Inhaled therapeutics for prevention and treatment of pneumonia. Expert Opin Drug Saf. 2009; 8(4): 435-49.

13. Rubino I, Oh E, Han $S$ et al. Salt coatings functionalize inert membranes into high-performing filters against infectious respiratory diseases. Sci Rep. 2020; 10: 13875.

14. Munoz AJ, Alasino RV, Garro AG et al. High concentrations of sodium chloride improve microbicidal activity of Ibuprofen against common cystic fibrosis pathogens. Pharmaceuticals. 2018; 11: 47.

15. Hypertonic saline coated face mask for reducing respiratory symptom severity in patients with COVID-19. https://clinicaltrials.gov/ct2/show/NCT04465604 (access: 2.08.2021).

16. Emeryk A, Pirożyński M. Nebulizacja: czym, jak, dla kogo, kiedy? Polski Konsensus Nebulizacyjny. Medycyna Praktyczna-Pneumonologia. 2013; 1: wyd. spec.: 2-8. 
17. Emeryk A, Pirożyński M, Mazurek H et al. Polski przewodnik inhalacyjny. $2^{\text {nd }}$ ed. Via Medica, Gdańsk 2021: 1-33.

18. Ari A. Jet, Ultrasonic, and Mesh Nebulizers: an evaluation of nebulizers for better clinical outcomes. Eurasian J Pulm. 2014; 16: 1-7.

19. Werżanowski P, Pirożyński M. Zestawienie inhalatorów dostępnych w Polsce. In: Pirożyński M. ABC nebulizacji ze szczególnym uwzględnieniem dawkowania. Via Medica, Gdańsk 2015: 43-72.

20. Martin AR, Finlay WH. Nebulizers for drug delivery to the lungs. Expert Opin Drug Deliv. 2015; 12(6): 889-900.

21. Pirożyński M, Florkiewicz E, Sosnowski TR. Podstawy nebulizacji - rodzaje inhalatorów. In: Pirożyński M (ed). ABC nebulizacji ze szczególnym uwzględnieniem dawkowania. Via Medica, Gdańsk 2015: 27-42.

22. Sayed NEE, Abdelrahman MA, Abdelrahim MEA. Effect of functional principle, delivery technique, and connection used on aerosol delivery from different nebulizers: An in-vitro study. Pulm Pharmacol Ther. 2021; 70: 102054.

23. Emeryk A, Pirożyński M, Mazurek $H$ et al. Stanowisko polskich ekspertów dotyczace nebulizacji $w$ okresie pandemii COVID-19. Terapia. 2020; 8(4 spec.): 12-8.

24. Nicolson $\mathrm{CH}$, Stirling RG, Borg BM et al. The long term effect of inhaled hypertonic saline 6\% in non-cystic fibrosis bronchiectasis. Respir Med. 2012; 106: 661-7.

25. Benjamin J, Tarrant BJ, Le Maitre C et al. Mucoactive agents for chronic, non-cystic fibrosis lung disease: A systematic review and meta-analysis. Respirology. 2017; 22: 1084-92.

26. Visser SK, Bye P, Morgan L. Management of bronchiectasis in adults. Med J Aust. 2018; 209(4): 177-83.

27. Pasteur MC, Bilton D, Hill AT; Thoracic Society Bronchiectasis (non-CF) Guideline Group. British Thoracic Society guideline for non-CF bronchiectasis. Thorax. 2010; 65: 1-58.

28. Zhang L, Mendoza-Sassi RA, Wainwright $C$ et al. Nebulized hypertonic saline solution for acute bronchiolitis in infants. Cochrane Database Syst Rev. 2008; 4: CD006458.

29. Ralston SL, Lieberthal AS, Meissner HC et al. Clinical practice guideline: the diagnosis, management, and prevention of bronchiolitis. American Academy of Pediatrics. Pediatrics. 2014; 134(5): e1474-e502.

30. Zhang L, Gunther CB, Franco OS et al. Impact of hypertonic saline on hospitalization rate in infants with acute bronchiolitis: a meta-analysis. Pediatr Pulmonol. 2018; 53(8): 1089-95.

31. Harrison W, Angoulvant F, House S et al. Hypertonic saline in bronchiolitis and type I error: a trial sequential analysis. Pediatrics. 2018; 142(3): e2018114449.

32. House SA, Gadomski AM, Ralston SL. Evaluating the placebo status of nebulized normal saline in patients with acute viral bronchiolitis. A systematic review and meta-analysis. JAMA Pediatr. 2020; 174(3): 250-9.

33. Elliott SA, Lindsay A Gaudet LA et al. Comparative Efficacy of Bronchiolitis Interventions in Acute Care: A Network Meta-analysis. Pediatrics. 2021; 147(5): e2020040816.

34. Buendia JA, Acuña-Cordero R. The cost-effectiveness of hypertonic saline inhalations for infant bronchiolitis. BMC Health Serv Res. 2020; 20(1): 1001.

35. GOLD 2021. 2021 Global strategy for prevention, diagnosis and management of COPD. https://goldcopd.org/2021-gold-reports (access: 2.08.2021).

36. Bennett WD, Henderson AG, Ceppe A. Effect of hypertonic saline on mucociliary clearance and clinical outcomes in chronic bronchitis. ERJ Open Res. 2020; 6: 00269-2020.

37. 2021 GINA Report, Global Strategy for Asthma Management and Prevention. https://ginasthma.org/wp-content/ uploads/2021/05/GINA-Main-Report-2021-V2-WMS.pdf (access: 2.08.2021).

38. Bennett WD, Burbank A, Almond M et al. Acute and durable effect of inhaled hypertonic saline on mucociliary clearance in adult asthma. ERJ Open Res. 2021; 7: 00062-2021.

ORCID

A. Emeryk - ID - http://orcid.org/0000-0003-1853-8696

J. Emeryk-Maksymiuk - ID - http://orcid.org/0000-0003-2709-0424

K. Janeczek - ID - http://orcid.org/0000-0002-8163-873X

A. Jędrzejewski - ID - http://orcid.org/0000-0001-8506-0851

Wkład autorów/Authors' contributions:

A. Emeryk: koncepcja, maszynopis; K. Janeczek: piśmiennictwo, maszynopis; J. Emeryk-Maksymiuk: piśmiennictwo, maszynopis; A. Jędrzejewski: maszynopis, weryfikacja piśmiennictwa.

Konflikt interesów/Conflict of interests:

Nie występuje.

Finansowanie/Financial support:

Nie występuje.

Etyka/Ethics:

Treści przedstawione w artykule są zgodne z zasadami Deklaracji Helsińskiej, dyrektywami EU oraz ujednoliconymi wymaganiami dla czasopism biomedycznych.

Copyright: @ Medical Education sp. z 0.0. This is an Open Access article distributed under the terms of the Attribution-NonCommercial 4.0 International (CC BY-NC 4.0). License (https://creativecommons.org/licenses/by-nc/4.0/), allowing third parties to copy and redistribute the material in any medium or format and to remix, transform, and build upon the material, provided the original work is properly cited and states its license.

Adres do korespondencji

\section{prof. dr hab. n. med. Andrzej Emeryk}

Klinika Chorób Płuc i Reumatologii Dziecięcej,

Uniwersytet Medyczny w Lublinie,

Uniwersytecki Szpital Dziecięcy w Lublinie

20-093 Lublin, ul. prof. Antoniego Gębali 6

tel.: (+48) 817185477

e-mail: emerykandrzej@gmail.com 